\title{
Perspektiewe vanuit die psigologie en sosiale wetenskappe vir kerklike bediening aan die adolessent. 'n Ondersoek na die ontwikkeling van die adolessent
}

J A Erasmus \& B J de Klerk

(Potchefstroomse Universiteit vir CHO)

\begin{abstract}
In this article meta-theoretical perspectives for youth ministry are presented from the fields of psychology and sociology. In the first place, it is determined what the various psychological development phases of the adolescent are, and how they have to be accounted for in youth ministry. In the second place, it is also determined what the characteristics of the world are in which the adolescent lives, and what their influences are on adolescents.
\end{abstract}

\section{INLEIDING}

Volgens die model van Zerfass (1974:166 ev) vir navorsing in praktiese teologie, moet daar rekening gehou word met kennis wat uit hulpwetenskappe verkrygbaar is en wat die spesifieke terrein wat bestudeer word, aanraak. Hierdie meta-teoretiese perspektiewe moet dan hermeneuties met die basisteoretiese riglyne en empiriese navorsing verwerk word, ten einde ' $\mathrm{n}$ aangepaste praktykteorie te vorm (Venter 1992:42-44; 1995:198-200).

In hierdie artikel word meta-teoretiese perspektiewe vanuit die psigologie en sosiale wetenskappe nagevors wat relevant kan wees vir doeltreffende kerklike bediening aan die adolessent.

Die meta-teoretiese perspektiewe sal vanuit twee hoeke bestudeer word:

- Ondersoek na die ontwikkeling van die adolessent;

- Ondersoek na die leefwêreld van die adolessent.

\section{ONDERSOEK NA DIE ONTWIKKELING VAN DIE ADOLES- SENT}

\section{Verantwoording}

In sy lewe gaan die mens deur verskillende ontwikkelingsfases. Soos alle lewende organismes volg die mens se ontwikkeling basies ' $\mathrm{n}$ geneties bepaalde plan (Louw 1992:6,14). Om doeltreffende bediening aan en deur die jeug te bied, behoort kennis gedra te word van hierdie ontwikkelingsfases waardeur die mens gaan. 
Adolessensie is ' $n$ goed beskryfde fase in psigologiese en opvoedkundige literatuur. Daarom gaan daar nie nou ' $n$ uitvoerige beskrywing van hierdie psigologiese fase gegee word nie maar sal slegs die hooftrekke aangetoon word.

\section{Biologiese veranderinge}

Die biologiese veranderinge wat intree by die aanvang van puberteit (geslagsrypheid) is die mees dramatiese in die ganse lewe van die individu, uitgesonderd die prenatale ontwikkeling. Hierdie biologiese veranderinge het ' $n$ groot invloed op die adolessent se gedrag en gedagtes omdat dit dikwels gepaard gaan met gevoelens van verwondering, trots, vreugde, maar ook onsekerheid, skaamte en weersin (Louw 1992:401). Liggaamlike en psigiese veranderings loop hand aan hand (Beukes 1993:32).

Gedurende vroeë adolessensie vind daar vinnige liggaamlike groei plaas, wat gepaard gaan met die ontwikkeling van primêre sowel as sekondêre geslagskenmerke. Dogters gaan ongeveer 18 maande vroeër as seuns puberteit binne. Daarom dat daar op ' $n$ spesifieke kronologiese stadium in die vroeë puberteit 'n opmerklike ontwikkelingsverskil tussen dogters en seuns is (Wigfield, Eccles \& Pintrich 1996:149).

Volgens beide Louw (1992:404-405) en Wigfield et al (1996:150) blyk dit dat vroeë puberteit en volwassenheid vir 'n seun voordelig kan wees wat betref deelname in sportaktiwiteit en sosiale stand in die skool. Sekere rolle soos leierskap word natuurliker aan hulle toegesê en hulle het ' $n$ hoë statusposisie in die portuurgroep. Hierdie adolessente se selfkonsep is dikwels beter as dié van adolessente wat laat ryp word. Soms word daar sekere verantwoordelikhede aan hierdie seuns toegesê omdat hulle volwasse lyk, maar dan word vergeet dat hulle nog nie is nie (vergelyk Van der der Schyff 1998:48). Hieruit kan volg dat die seuns dan nie aan die sosiale verwagtings kan voldoen nie. Seuns wat laat liggaamlike rypheid bereik, word baie keer gesien as minder aantreklik, minder gebalanseerd, meer geaffekteerd, gespanne en angstig. Soms ervaar hulle minderwaardigheidsgevoelens teenoor hulle ouderdomsgroep (Wigfield et al 1996:149-150).

Onder psigoloë is daar uiteenlopende standpunte oor die waarde van vroeë geslagsrypheid vir 'n dogter. Wigfield et al (1996:150) sê dat vroeë puberteit dikwels vir die dogter problematies kan wees omdat sy dan uit pas met haar ouderdomsgroep kan voel. Navorsing het getoon dat meisies wat vroeg in puberteit ingegaan het, die laagste selfagting gehad het en die moeilikste aangepas het in die verandering van laerskool na hoërskool. Louw (1992:405-406) sê daarenteen dat meisies wat vroeg ryp word meer selfvertroue, minder angstigheid, 'n groter mate van rustigheid 
en selfversekerdheid toon en makliker by veranderinge aanpas. Tog erken hy dat die situasie problematies kan raak omdat sy nie altyd veel met haar portuurgroep gemeen het nie en dit haar kan isoleer.

\section{Kognitiewe ontwikkeling}

Met die aanbreek van puberteit beskik die jeugdige oor die maksimum breinmassa (Van der Westhuizen 1989:20). Die adolessent se kognitiewe vermoë ontwikkel kwalitatief en kwantitatief - kwantitatief in die sin dat die adolessent intellektuele take makliker, vinniger en effektiewer kan bemeester, en kwalitatief in die sin van verandering ten opsigte van die aard van die denkprosesse en die kognitiewe struktuur. Adolessente se geheue verbeter in so ' $n$ mate dat hulle baie meer inligting kan opberg as tydens die kinderjare. Dit stel hulle in staat om probleme op te los wat die vermoë vereis om heen en weer te beweeg tussen inligting wat so pas geënkodeer is en dié wat vroeër in hul geheue geberg is (Louw 1992:417418).

Gedurende adolessensie begin die jongmens abstrak en logies dink. Hulle is nie meer so direk gebonde aan die direkte, die konkrete ervaring of demonstrasie nie. Nie-beredeneerbare data word nie bloot aanvaar nie - daar is ' $\mathrm{n}$ soeke na wetenskaplik aanvaarbare verklarings (Beukes 1993:33). Omdat die adolessente begin onderskei tussen hipotese en feite, kan hulle oor beginsels begin redeneer. Daar word ook makliker oor langer periodes gekonsentreer as voorheen, en omdat aspekte soos ruimte, tyd en tydelikheid nuwe betekenis kry, is die adolessent in staat tot insig in sake wat voorheen onverstaanbaar was (Van der Westhuizen 1989:20).

Wigfield et al (1996:151) sê dat die belangrikste kognitiewe veranderinge wat met adolessensie plaasvind, die toenemende vermoë is om abstrak te dink, om hipoteses sowel as werklikhede in ag te neem, om op meer gesofistikeerde en breedvoerige wyses inligting te verwerk en om oor die self en ingewikkelde probleme na te dink. Daarom behoort adolessente meer effektiewe en gesofistikeerde leerders te wees wat relatief gevorderde temas op verskeie vakgebiede kan baasraak.

Adolessente begin nadink oor stellings wat nie aan konkrete voorwerpe gekoppel kan word nie. Hulle dink byvoorbeeld na oor religieuse begrippe, soos die bestaan van God; wetenskaplike onderwerpe; eietydse strydvrae; sosiale, politieke en persoonlike waardes; en die uniekheid van sy kenmerke en gevoelens. Adolessente se kognitiewe vermoëns stel hulle ook in staat tot asketisme en intellektualisering. Asketisme word gebruik in die sin dat adolessente in die naam van religieuse toewyding seksuele bevrediging vermy. Intellektualisering kom weer voor wanneer die adolessent oor sensitiewe 
sake onpersoonlike, abstrakte of filosofiese besprekings voer (Louw 1992:418, 426).

Daar is volgens Wigfield et al (1996:152) nie 'n noemenswaardige verskil in die kognitiewe ontwikkeling tussen seuns en dogters nie en beide groepe presteer ewe goed op alle vakgebiede. Tog is dit interessant dat seuns meer wiskundige en wetenskaplike belangstellings het, terwyl dogters meer geesteswetenskaplike belangstellings toon.

\section{Morele ontwikkeling}

Moraliteit het te doen met ' $\mathrm{n}$ individu se vermoë om te onderskei tussen goed en kwaad en om daarvolgens te handel. ' $n$ Mens se morele identiteit is ' $\mathrm{n}$ dimensie van jou persoonlike identiteit. Omdat ' $\mathrm{n}$ primêre ontwikkelingstaak van adolessente die ontwikkeling van ' $n$ eie identiteit is, moet doelbewus aandag gegee word aan die morele ontwikkeling van adolessente (Prins 2001:105, 107-108).

Daar is ' $n$ baie nou band tussen kognitiewe ontwikkeling en morele ontwikkeling. Lawrence Kohlberg koppel die vlakke wat hy in die morele ontwikkeling van die mens onderskei aan die stadia wat deur Piaget in kognitiewe ontwikkeling onderskei word (Richards 1983:100). Hiervolgens word morele gedagtes bepaal deur die ontwikkeling van kognitiewe strukture.

In sy latere werk onderskei Kohlberg ses vlakke waarop ' $n$ mens moreel kan funksioneer. Dit is moontlik dat ' $n$ gegewe adolessent op enige van vier van hierdie vlakke kan wees (Louw 1992:429-430):

- Op vlak 3 word morele oordeel bepaal deur dit waarvan ander mense hou en wat hulp aan ander kan verleen. Daar word gepoog om kritiek te vermy en goedkeuring te ontvang.

- Op vlak 4 word korrekte gedrag geassosieer met pligsvervulling, respek vir outoriteit, en handhawing van bestaande sosiale wet en orde.

- Op vlak 5 word korrekte of verkeerde gedrag gedefinieer op grond van vasgestelde wette of reëls wat betrekking het op algemene standaarde. Die reëls het ' $n$ rasionele basis en bevorder die welsyn van die samelewing. Benewens die konformering met algemene standaarde, dien die individu se persoonlike waardes en menings ook as maatstaf vir wat korrek of verkeerd is.

- Op vlak 6 word die individu se gedrag nie net volgens bestaande norme beoordeel nie, maar ook volgens sy gewete en selfgekose geïnternaliseerde abstrakte etiese beginsels. Die persoon wat hierdie 
vlak van morele oordeel bereik, tree volgens sy beginsels op - ongeag ander se reaksie.

Die saak waaroor dit hier gaan, is die vermoë om 'n waardeoordeel te kan fel. ' $n$ Kind wat byvoorbeeld die regte ding doen bloot om 'n onderwyser te plesier, maak nie ' $n$ waardeoordeel nie. Dit gebeur slegs wanneer die situasie ' $n$ keuse laat en daar op die basis van beredenering ' $n$ oordeel volgens eie oortuigings en beginsels gemaak word (Richards 1983:151).

Van der Schyff (1998:51) sê dat die abstrakte denkvermoë wat die adolessent ontwikkel, veroorsaak dat vrae ontstaan rondom geloofs-, etiese, morele en kerklik-leerstellige kwessies. Waar hulle as jong kinders onvoorwaardelik geglo het wat aan hulle voorgehou is, bevraagteken hulle as adolessente bykans alles wat aan hulle voorgehou word. Die portuurgroep word as ' $\mathrm{n}$ baie belangrike faktor in morele ontwikkeling van die adolessent gesien (Louw 1992:431). Die groep stel standaarde en gedragsbeperkings waarmee adolessente konformeer omdat die portuurgroep vir hulle baie belangrik is.

Ander faktore wat ' $\mathrm{n}$ invloed op morele ontwikkeling het, is sosiale rolvervulling en sosiale leer. Sosiale rolvervulling en sosiale leer vind plaas wanneer kinders blootgestel word aan 'n aantal mense. Die kind moet dan bewus gemaak word dat verskillende mense anders as hy is en moontlik ander standpunte en gevoelens as hy kan hê. Deur verskeie metodes (byvoorbeeld rolmodeloptrede as versterking van gedrag) kan die kind geleer word om ander standpunte in ag te neem. Hierdie onderrig kan nie net sosiale redenering stimuleer nie, maar dit ook motiveer (Richards 1983:157-158).

\section{Emosionele ontwikkeling}

Hoe ouer kinders raak, hoe ingewikkelder word die emosionele funksionering. Hierdie komplekse funksionering is waarneembaar. Gedurende adolessensie is die sosiale wording die groeibodem en oorsprong van emosionele aktiwiteite. Op hierdie ouderdom vrees die jeugdige om in die teenwoordigheid van die ander lede van die portuurgroep uitgesonder te word. Opvoeders moet versigtig wees vir beledigings in die openbaar want dit kan aanleiding gee tot ' $n$ magtelose opwelling van emosies (Van der Westhuizen 1989:22-23).

Van't Zand (1995:193) toon aan dat adolessente hulself soek en wil weet wat hulle beperkings en potensiaal is. Hulle wil weet wie hulle in vergelyking met ander is. Hulle wil weet of hulle belangrik in die oë van hulle ouers is, en of hulle die regte besluite kan neem. Hulle wil weet of hulle hul eie pad kan loop. Hulle besit 'n sterk behoefte aan veiligheid en 
sekuriteit en wil graag deur ander mense aanvaar word. Daarom is adolessente gedurig op ' $n$ soeke na erkenning dat hulle goed genoeg is.

Van der Schyff (1998:49-50) sê dat die volgende emosionele behoeftes kenmerkend van adolessente is:

- Stabiliteit binne die gesin. Omdat onstabiliteit een van die sterkste kenmerke van adolessente is, het hulle stabiliteit binne die gesin nodig om hulself te onderskraag. Die voorbeeld van ouers kan geborgenheid verseker in 'n tydperk waarin die adolessent na sy eie identiteit soek.

- Leiding versus vryheid. In samehang met die behoefte aan stabiliteit het elke adolessent ' $n$ behoefte aan leiding. Adolessente verkeer in ' $n$ fase om hulself te leer ken en daarvoor is leiding van ' $n$ volwassene nodig. Tog het adolessente die strewe na vryheid en onafhanklikheid om hulself te laat geld. Hierdie strewe na vryheid moet gerespekteer word.

- Liefde. Adolessente wil die versekering hê dat, ten spyte van hulle onstabiliteit, impulsiwiteit, soeke na aandag, rebelsheid en ander tipiese karaktertrekke van die stadium waarin hulle hul bevind, ander nog steeds lief is vir hulle. Liefde is die heel sterkste behoefte van alle mense.

Adolessensie word dikwels die tydperk van storm en drang genoem. Volgens Richards (1978:62-63,69) is hierdie term nie altyd regverdig nie want daar is ook baie tye van kalmte en stabiliteit. Tog is dit vir adolessente moeilik om hulself te vind. Identiteitvorming gaan gepaard met konflik en probleme wat deurleef moet word. Hierdie emosionele onstabiliteit bring dikwels gevoelens wat adolessente nie kan verstaan nie en wat tot neerslagtigheid kan lei. Sensitiwiteit word daarom benodig vir adolessente se emosies en buie. Hierdie emosies en buie is dikwels bloot simptome van innerlike worstelings.

\section{Sosiale ontwikkeling}

Gedurende adolessensie worstel ' $n$ tiener om sigself te leer verstaan. Omdat daar ' $\mathrm{n}$ strewe na onafhanklikheid is, kom hulle dikwels in opstand teen volwassenes, veral wanneer hulle meen dat hulle soos kinders behandel word. In hierdie strewe na onafhanklikheid steun adolessente sterk op die portuurgroep (Van der Westhuizen 1989:21). Hoe ander teenoor hulle optree en reageer is belangrik. Hul eiewaarde is gekoppel aan die waarde wat ander aan hulle heg. Die waarde wat aan die opinie van ander adolessente geheg word, kom na vore in die jeugsubkultuur: haarlengtes, klere, musiek, ensovoorts (Richards 1978:76-77). 
' $n$ Faktor wat die belang van die portuurgroep versterk, is die behoefte van adolessente om hulself as individue buite die ruimte van die familie te verstaan. Adolessente versterk hul eie gevoel van identiteit deur deel te wees van ' $n$ groep wat hul andersheid van die ouers beklemtoon (Richards 1978:81). In adolessensie beleef die kind ' $n$ proses van losmaking van ouerlike bindinge ten einde ' $n$ eie waardestelsel te internaliseer (Prins 1995:51).

In die portuurgroep word warmte, aanvaarding en sekuriteit aan adolessente verskaf. Tieners sal bykans enigiets doen om deur die groep aanvaar te word en belê dan ook ' $n$ groot hoeveelheid energie daarin om deel van die groep te word en te wees (Van't Zand 1995:194). Seuns en dogters wat fisies sonder agterstand en gebreke is, word normaalweg maklik deur die groep aanvaar. Diegene wat egter nie volkome deur die portuurgroep aanvaar word nie, kan aan hulself begin twyfel en nog minder aanvaarbaar optree en uiteindelik heeltemal deur die groep uitgeskuif word (Van der Westhuizen 1989:22). Adolessente moet geleer word om 'n oog vir ander te hê en uit te reik na dié wat uitgeskuif word.

Alhoewel die druk van die portuurgroep afbrekend kan wees, kan dit ook die waardes van die ouers versterk (Van't Zand 1995:195). Navorsing toon dat die klem op die portuurgroep nie beteken dat daar ' $\mathrm{n}$ totale verwerping van die ouers se lewenswyse is nie. Baiekeer is daar ooreenstemming tussen die waardes van die ouers en dié van die portuurgroep. Adolessente is geneig om vriende te kies wie se waardes met dié van hul ouers ooreenstem.

Ten opsigte van sake wat op basiese waardes berus, naamlik godsdiens, morele en sosiale gedrag, word daar eerder op die ouers se raad en leiding gesteun. Die portuurgroep se opinie is weer belangriker by sake soos kleredrag, vermaak en verhoudings met die teenoorgestelde geslag (Louw, 1992:442-443). Beukes (1993:33) sê dat die invloed van die portuurgroep hoofsaaklik beperk is tot korttermynaangeleenthede, terwyl die ouers se invloed ' $n$ belangrike rol speel in langtermynaangeleenthede.

' $n$ Nadeel van die portuurgroep is dat jongmense ' $n$ masker kan opsit sodat hulle dan nie hul ware self is nie (Richards 1978:83-84). Adolessente moet geleer word om hulself te aanvaar en te strewe om te word wat hulle reeds in Christus is. Omdat rolmodelle buite die gesin ook ' $n$ invloed op die sosiale ontwikkeling van adolessente het (Van der Schyff 1998:51), kan volwassenes in die kerk daarna streef om rolmodelle vir die jeug te wees en deur lewensvoorbeeld die regte norme en waardes aankweek. 


\section{Meta-teoretiese perspektiewe vanuit die beskrywing van adolessensie as psigologiese ontwikkelingsfase}

Die volgende meta-teoretiese perspektiewe kan uit die beskrywing van adolessensie as psigologiese ontwikkelingsfase afgelei word:

a) Psigologies speel die biologiese veranderinge wat adolessente ondergaan ' $n$ groot rol. Wanneer met vroeë adolessente gewerk word, moet rekening daarmee gehou word dat die dogters meer volwasse sal wees as die seuns. ' $n$ Meer volwasse benadering tot die dogters sal meer vrugte afwerp. Terselfdertyd moet met elke individu in die groep se ontwikkelingstand rekening gehou word. Sommige is meer volwasse as ander. Individualisering is hier van belang omdat almal nie oor dieselfde kam geskeer kan word nie.

b) Die kognitiewe veranderinge wat adolessente deurmaak, stel hulle in staat om beter te onthou en meer ingewikkeld te dink. Intellektuele take kan makliker, vinniger en effektiewer bemeester word en daar word ook langer gekonsentreer. Geloofsonderrig kan dus tydens langer klasse plaasvind en meer werk kan behandel word as met jonger kinders. Abstrakte geloofswaarhede kan aan die adolessent voorgehou word en 'n onderskeid kan tussen werklikheid en ideaal getref word. Adolessente begin selfstandig dink en daarom moet leiding gegee word in die oorweging van etiese en morele vraagstukke.

c) Die morele ontwikkeling van kinders word gekoppel aan hulle kognitiewe ontwikkeling. Abstrakte denkvermoë maak dit moontlik om krities te begin dink oor sake wat tevore bloot aanvaar is.

Alhoewel die waardes van die portuurgroep teenoor dié van die ouers en kerk kan verskil en dus problematies kan wees, is dit nie noodwendig altyd die geval nie. Konformering met die portuurgroep kan daartoe bydra dat waardes wat deur die ouers en die kerk aangeleer word, versterk word - veral as adolessente aangemoedig word om maats te wees met portuurs wat dieselfde waardeoriëntasie het as wat in die ouerhuis bestaan (Louw 1992:431).

Leiding aan adolessente in die besluitneming oor morele kwessies is dus uiters noodsaaklik. Daar moet opgelet word na die morele inhoud van dit waarin adolessente onderrig word. ' $n$ Korrekte morele voorbeeld deur die ouers en ander geloofsgenote is uiters noodsaaklik. Daar moet doelgerig gewerk word om die adolessent te leer om korrekte morele besluite te neem. Adolessente moet dus sodanig met die Woord van die Here gekonfronteer word dat hy dit sal aanvaar as reël en riglyn vir sy lewe. 
d) Die emosionele ontwikkeling van adolessente is nou gekoppel aan hulle sosiale wording. Weens die wisselvalligheid van hul emosionele staat, soek adolessente na mense wat hulle onvoorwaardelik aanvaar en liefhet. Die ouerhuis en die kerk moet voorsien in die behoeftes van liefde, leiding en stabiliteit, maar moet adolessente ook vryheid gee om hulself te vind. Geduld moet deur die adolessent beoefen word, want baie van die wisselvallige emosies is simptome van innerlike worstelings.

Emosionele wisselvalligheid is dikwels die oorsaak dat adolessente as gevolg van ' $\mathrm{n}$ oordrewe skuldbesef in diepe neerslagtigheid verval. Van der Westhuizen (1989:23) vra tereg die vraag of dit geregverdig is dat kerke op hierdie ouderdom die (kerklike) jeugdiges probeer "bekeer" voordat hulle as lidmate aanvaar word. Hierdie pogings kan eindig in geestelik ontspoorde jongmense. Die jeuglidmaat moet eerder deur die skuldbesef en neerslagtigheid begelei word met opregte pastorale liefde.

e) Sosiale omgang met ander van dieselfde portuurgroep is vir die ontwikkeling van adolessente van die uiterste belang. Jeugwerk moet hiermee rekening hou.

Opvoeding wat jongmense dwing om portuurgroep-bande te breek, plaas geweldige druk op adolessente. Deur te strewe na ' $n$ sterk Christelike portuurgroep kan 'n geweldige impak gemaak word. Deur middel van die portuurgroep kan jeuglidmate leer om mekaar met woord en daad te dien.

Daar moet egter gewaak word om die individu nie in die groep te verloor nie. Jongmense moet geleer word om hulself te wees en nie dinge te doen bloot om die goedkeuring van die groep te verkry nie. Adolessente moet geleer word om ook ' $n$ oog vir mense buite die portuurgroep te hê en teenoor alle mense Christelike liefde uit te straal.

Ten spyte van die klem op die portuurgroep het ouers nog 'n geweldige impak op die sosiale vorming van hul adolessente en hulle moet steeds leiding gee. Hierdie leiding moet gegee word met begrip vir die mate van volwassenheid van hul kind. Ander volwassenes in die kerk moet daarna strewe om rolmodelle vir die jeug te wees in hul navolging van Christus.

\section{Literatuurverwysings}

Berliner, D C \& Calfee, R C (eds) Handbook of educational psychology. New York: Macmillan. (Petrus, ek weet nie of hierdie reg is nie) 
Beukes, M J du P 1993. ' $\mathrm{n}$ Prakties-teologiese visie op die begeleiding van adolessente deur die kerk. Praktiese Teologie in Suid-Afrika 8(1), 29-41.

Klostermann, F \& Zerfass, R (Petrus help hier asb)

Louw, D A 1992. Menslike ontwikkeling (Tweede uitgawe). Pretoria: HAUM Tersiêr.

Prins, J M G 2001. Intensionele morele vorming: noodsaaklik in kerklike jeugbediening. Praktiese Teologie in Suid-Afrika 16(1), 105-119.

Richards, L O 1978. Youth ministry - its renewal in the local church. Grand Rapids, Michigan: Zondervan.

-, 1983. A theology of children's ministry. Grand Rapids, Michigan: Zondervan.

Van der Schyff, S P 1998. Herderlike bediening aan die kind uit ' $n$ egskeidingsgesin. Potchefstroom: PU vir CHO (Ongepubliseerde verhandeling - Th.M).

Van der Westhuizen, J P 1989. Opvoedkundig-sielkundige temas vir onderwysstudente. Durban: Butterwoths.

Van't Zand, J D 1995. Eenheid en verskeidenheid. 'n Model vir Jeugbediening in die Gereformeerde Kerke in Suid-Afrika. Potchefstroom: PU vir CHO. (Verhandeling - Th.M.)

Venter, C J H 1992. Diakoniologie en rasionaliteit - 'n verkenning. In die Skriflig 26(1),29-51.

-, 1995. Die Woord in die werklikheid. Wetenskapsteoretiese perspektiewe op Diakoniologie. In die Skriflig, 29(1\&2), 181-202.

Wigfield, A, Eccles, J S \& Pintrich, P R 1996. Development between the ages of 11 and 25. In: Berliner, D C \& Calfee, R C (eds), Handbook of educational psychology. New York: Macmillan, 148-185.

Zerfass, R 1974. Praktische Teologie als Handlungswissenschaft. In: Klostermann, F \& Zerfass, R Praktische Teologie heute. Munchen: Kaiser, 164-177. 